\title{
Analysis on Identification Level of Football Fans with Their Teams in Eastern and Southeastern Anatolia Region
}

\author{
Özgür Karataş ${ }^{1}$, Abdullah Bingölbalı ${ }^{1}$ \\ ${ }^{1}$ İnonu Unıversty Sports Science Faculty Malatya Turkey \\ Correspondence: İnonu Unıversty Sports Science Faculty Malatya Turkey.
}

Received: January 28, 2019

Accepted: February 24, 2019 Online Published: February 26, 2019

doi:10.11114/jets.v7i3.4098

URL: https://doi.org/10.11114/jets.v7i3.4098

\begin{abstract}
Purpose: The purpose of this study is to analyze the identification level of football fans with their teams in Eastern and Southeastern Anatolia Region.

Material and method: General screening model, which is one of the descriptive methods, was used in the research. The research contains 944 people being the fans of 7 football teams (Yeni Malatyaspor in the Super League, Büyükşehir Belediye Erzurumspor, Elazığspor, Gaziantepspor, Gazişehir Gaziantepspor in the $1^{\text {st }}$ League and Amed sportif faaliyetler, Sanliurfaspor in the $2^{\text {nd }}$ League) in Eastern and Southeastern Anatolia Region playing in Super League, $1^{\text {st }}$ League and $2^{\text {nd }}$ League during 2017-2018 football season. As the data collection tool of the study, 'Sports Fan Identification Scale' developed by Wann and Branscompe (1993) and translated into Turkish by Günay and Tiryaki (2003) with validity and reliability studies performed was used. 0.88 value was found as the Cronbach Alpha coefficient of the Sports Fan Identification Scale. The significance level was adopted as $\alpha=0.05$.
\end{abstract}

Findings: It has been determined that there are significant differences between the variables of age, marital status and the teams supported and the mean scores on identification level of fans with their teams $(p<0.05)$ while no significant difference has been ascertained between the variables of education, job and income level and the mean scores on identification level of fans with their teams $(\mathrm{p}>0.05)$.

Conclusion: It has been concluded that mean scores of fans on their identification level with their teams playing in high leagues are high and the fans' level of identification with the teams has decreased as the lower leagues are considered.

Keywords: football, fan, identification

\section{Introduction}

The sports activity and service expectations of people in social life are met by the sports clubs, which are the main organizational units in the sports. Sports clubs play an important role in transforming sports into a lifestyle and applying it to life as a discipline (Taşmektepligil et al., 2006). Sports clubs are the smallest organizations in sports area. Every organization and club has a purpose and interaction with the environment. The performance and achievements of sports clubs most clearly reveal whether sports clubs have reached their targets. Actually, the main purpose of sports clubs is to be successful in sports area (İmamoğlu et al., 2007).

Participation in sports activities as a spectator continues to be very intense since the first years when people's need for recreation was on the agenda (Karaküçük, 2005). Many people follow sports events through the media, spend their free time by doing sports, watch sports events in situ and even acquire sports as a profession by considering sports as a way to earn their lives. Sports audience in our country, especially football, can be said to be mostly performed activity in relation to sports (Aycan et al., 2009).

Football allows people to be discharged, relaxed and happy. Football can enable the masses to unite and socialize around a common goal. Football has become the passion of people not only in our country but in many countries around the world (Gündüz and Bayansalduz, 2017). The interest in football is too big to compare with other sports branches (Açak and Karabulut, 2016). Professional football teams and fans complement each other. These two elements have formed in line with the each other's demands. It is impossible to talk about one of them without the other. The weakness of any of such interrelated elements may affect the other side (İmamoğlu et al., 2016).

Sports fans have different characteristics. Some people are loyal supporters of a team, participate regularly in their 
team's matches and establish emotional ties with their team and players. A person feels the trust of being attached to a group with the team supported, badge s/he wears, the colors carried, uniform, rigging, the national anthem, the flag, the national success and slogans. He saves his personality from being "nothing" by adopting that group. That person believes that $\mathrm{s} / \mathrm{he}$ has a role and place in the society by seeing herself/himself as a member of the group. S/he communes and identifies with cultural and sports images of the team supported. Some other people have low involvement. They do not prefer to support a team since they do not have any interest in the field of sports, or even if they support a team, they may be irrelevant to the team's matches (Enginkaya, 2014; Okur, 2014).

Identification with the team is the psychological connection of a fan with a team or the scope of being interested in a team psychologically. In identification with the team, the person feels sorry if the team supported loses and feels happy with the achievement of athlete (Güllü and Güçlü, 2006). Identification with a sports team involves identifying one's own identity in terms of loyalty to the team; thus, sports team actually become a part of the individual's own identity (Belk, 1988; Madrigal, 2000).

Underwood et al. (2001) have stated that group experience (feeding the sense of belonging), continuously reminding the history and traditions of their team, creating a unique stadium atmosphere and encouraging ritual-based behaviors can be used by teams to increase identification/commitment feelings of their own fans.

It is important for the football teams to get the support of their fans named as the twelfth man in achieving success. Determining the identification level of fans with their teams is important in terms of eliminating the shortcomings of the teams and providing better services for the fans. The purpose of this study is to analyze the identification levels of football fans with their teams in Eastern and Southeastern Anatolia Region.

\section{Material and Method}

The research population contains 944 voluntary people being the fans of 7 professional football teams (Yeni Malatyaspor in the Super League, Büyükşehir Belediye Erzurumspor, Elazığspor, Gaziantepspor, Gazişehir Gaziantepspor in the $1^{\text {st }}$ League and Amed sportif faaliyetler, Şanlıurfaspor in the $2^{\text {nd }}$ League) in Eastern and Southeastern Anatolia Region playing in Super League, $1^{\text {st }}$ League and $2^{\text {nd }}$ League during 2017-2018 football season while the sample is composed of 944 voluntary fans of these teams.

As the data collection tool of the study, 'Sports Fan Identification Scale' was used. The scale was developed by Wann and Branscompe (1993). It was translated into Turkish by Günay and Tiryaki (2003) and its validity and reliability studies were performed. This is a one-dimensional, 7-point Likert type scale ranging from 1 to 8 . Cronbach's Alpha coefficient belonging to the Sports Fan Identification Scale in our research was found to be 0.88 . The value of $\alpha=0.05$ was established as significance level.

Sports Fan Identification Scale used in the research were randomly distributed to the fans who went to the matches of Yeni Malatyaspor, Büyükşehir Belediye Erzurumspor, Elazığspor, Gaziantepspor, Gazişehir Gaziantepspor, Amed sportif faaliyetler and Şanliurfaspor teams via face-to-face interview technique by the researchers (by using 15 poll takers). Before filling the Sports Fan Identification Scale, the participants were informed about the scale and they were ensured to fill properly.

\section{Findings}

Table 1. Identification level of fans with their teams by the variable of age

\begin{tabular}{|c|c|c|c|c|c|c|}
\hline Age & $\mathbf{N}$ & $X$ & SS & $\begin{array}{l}\text { Kruskal-Wallis } \\
\text { Test }\end{array}$ & Sig. & Difference \\
\hline $15-20$ & 255 & 3.81 & 0.85 & \multirow{6}{*}{-11.077} & \multirow{6}{*}{$0.026^{*}$} & \multirow{6}{*}{$\begin{array}{l}15-20>21-26 \\
21-26>33-38\end{array}$} \\
\hline $21-26$ & 226 & 3.78 & 0.82 & & & \\
\hline $27-32$ & 162 & 3.79 & 0.58 & & & \\
\hline $33-38$ & 176 & 3.75 & 0.44 & & & \\
\hline $39+$ & 125 & 3.78 & 0.61 & & & \\
\hline Total & 944 & 3.78 & 0.71 & & & \\
\hline
\end{tabular}

$(\mathrm{p}<0.05)$.

Looking at Table 1, it has been determined that the difference between the mean scores on identification level of fans with their teams by the variable of age is significant $(\mathrm{p}<0.05)$. It has been established following the results that mean score of the identification level of fans aged $15-20$-with their teams $(X=3.81)$ is significantly higher than the mean score of the identification level of fans aged 21-26 ( $X=3.78)$ with their teams; the mean score of the identification level of fans aged 21-26 ( $X=3.78)$ is significantly higher than the mean score of the identification level of fans aged 33-38 $(\mathrm{X}=3.75)$. 
Table 2. Identification level of fans with their teams by the variable of marital status

\begin{tabular}{llllll}
\hline Marital status & $\mathbf{N}$ & $\mathbf{X}$ & ss & Mann-Whitney U & p \\
\hline Married & 358 & 3.76 & 0.56 & & \multirow{2}{*}{-2.885} \\
\hline Single & 586 & 3.80 & 0.78 & $004^{*}$ \\
\hline Total & 944 & 3.78 & 0.71 & & \\
\hline
\end{tabular}
$(\mathrm{p}<0.05)$.

Looking at Table 2, it has been determined that the difference between the mean scores on identification level of fans with their teams by the variable of marital status is significant $(\mathrm{p}<0.05)$. The mean score of the identification level of single fans ( $X=3.80$ ) with their teams-was found to be significantly higher than the mean score of the identification level of married fans with their teams $(X=3.76)$.

Table 3. Identification level of fans with their teams by the variable of education

\begin{tabular}{llllll}
\hline Education & N & X & Ss & $\begin{array}{l}\text { Kruskal-Wallis } \\
\text { Test }\end{array}$ & p \\
\hline Primary School & 234 & 3.89 & 0.53 & & \\
\hline High School & 415 & 3.79 & 0.73 & 5.215 & .074 \\
\hline University & 297 & 3.69 & 0.78 & \\
\hline Total & 944 & 3.78 & 0.71 & \\
\hline
\end{tabular}

$(\mathrm{p}>0.05)$

Looking at Table 3, it has been determined that the difference between the mean scores on identification level of fans with their teams by the variable of education is insignificant $(\mathrm{p}>0.05)$.

Table 4. Identification level of fans with their teams by the variable of job

\begin{tabular}{lllll}
\hline Job & $\mathbf{N}$ & $\mathrm{X}$ & SS & Kruskal-Wallis Test $\mathbf{p}$ \\
\hline Self-employed & 108 & 3.84 & 0.64 & \\
\hline Civil servant & 144 & 3.79 & 0.63 \\
\hline Worker & 141 & 3.84 & 0.62 \\
\hline Student & 354 & 3.76 & 0.83 \\
\hline Tradesman & 101 & 3.73 & 0.50 \\
\hline Other & 30 & 3.70 & 0.67 \\
\hline Total & 944 & 3.78 & 0.71 & .232 \\
\hline O5) & &
\end{tabular}

$(\mathrm{p}>0.05)$

Looking at Table 4, it has been determined that the difference between the mean scores on identification level of fans with their teams by the variable of job is insignificant $(\mathrm{p}>0.05)$.

Table 5. Identification level of fans with their teams by the variable of income level

\begin{tabular}{|c|c|c|c|c|c|}
\hline Income level & $\mathbf{N}$ & $\mathrm{X}$ & SS & Kruskal-Wallis Test & $\bar{p}$ \\
\hline Very poor & 51 & 3.69 & 0.94 & \multirow{6}{*}{-.061} & \multirow{6}{*}{1.000} \\
\hline Poor & 115 & 3.82 & 0.61 & & \\
\hline Moderate & 452 & 3.81 & 0.63 & & \\
\hline Good & 220 & 3.73 & 0.82 & & \\
\hline Very good & 106 & 3.78 & 0.71 & & \\
\hline Total & 944 & 3.78 & 0.71 & & \\
\hline
\end{tabular}
$(\mathrm{p}>0.05)$

Looking at Table 5, it has been determined that the difference between the mean scores on identification level of fans with their teams by the variable of income is insignificant $(p>0.05)$.

Table 6. Identification level of fans with their teams by the variable of team supported

\begin{tabular}{|c|c|c|c|c|c|c|}
\hline Team supported & $\mathbf{N}$ & $\mathrm{X}$ & SS & $\begin{array}{l}\text { Kruskal-Wallis } \\
\text { Test }\end{array}$ & $\mathbf{p}$ & Difference \\
\hline Elazı̆̆spor $\quad(1)$ & 135 & 3.95 & 0.73 & \multirow{8}{*}{34.899} & \multirow{8}{*}{.000} & \multirow{8}{*}{$\begin{array}{l}1>3,7 \\
2>3,6,7 \\
3<4,5\end{array}$} \\
\hline Yeni Malatyaspor (2) & 138 & 3.98 & 0.59 & & & \\
\hline Amed sportif faaliyetler (3) & 136 & 3.44 & 0.97 & & & \\
\hline Büyükşehir Belediye Erzurumspor (4) & 132 & 3.85 & 0.50 & & & \\
\hline Gazişehir Gaziantep football club (5) & 139 & 3.85 & 0.55 & & & \\
\hline Gaziantepspor (6) & 133 & 3.72 & 0.73 & & & \\
\hline Şanliurfaspor (7) & 131 & 3.69 & 0.62 & & & \\
\hline Total & 944 & 3.78 & 0.71 & & & \\
\hline
\end{tabular}

$(\mathrm{p}<0.05)$. 
Looking at Table 6, it has been determined that the difference between the mean scores on identification level of fans with their teams by the variable of team supported is significant $(p<0.05)$. It has been determined that this difference emerges between the fans of Elazığspor and Şanlıurfaspor, Yeni Malatyaspor and Amed sportif faaliyetler, Elazığspor and Amed sportif faaliyetler, Büyükşehir Belediye Erzurumspor and Amed sportif faaliyetler, Gazişehir Gaziantep football club and Amed sportif faaliyetler, Gaziantepspor and Yeni Malatyaspor, Şanlıurfaspor and Yeni Malatyaspor teams. It is observed that the fans of Yeni Malatyaspor team have identified with their teams more than the fans of other teams $(\mathrm{X}=3.98)$.

\section{Discussion and Conclusion}

Looking at Table 1, it has been determined that the difference between the mean scores on identification level of fans with their teams by the variable of age is significant $(\mathrm{p}<0.05)$. It has been established following the results that mean score of the identification level of fans aged $15-20$-with their teams $(X=3.81)$ is significantly higher than the mean score of the identification level of fans aged 21-26 ( $X=3.78)$ with their teams; the mean score of the identification level of fans aged 21-26 ( $\mathrm{X}=3.78)$ is significantly higher than the mean score of the identification level of fans aged 33-38 ( $X=3.75$ ). Our findings comply with the results of researches conducted by Baş (2008), Baran (2015), Açak et al. (2018), Gencay and Karaküçük (2006). In the researches on different fields, Polat (2009) and Işık (2016) have stated that the difference between the mean scores of identification level and age is significant. It can be said that the identification levels of the fans at the age group of 15-20 with their teams are higher than the other age groups.

Looking at Table 2, it has been determined that the difference between the mean scores on identification level of fans with their teams by the variable of marital status is significant $(p<0.05)$. The mean score of the identification level of single fans $(X=3.80)$ with their teams was found to be significantly higher than the mean score of the identification level of married fans with their teams ( $X=3.76$ ). Our findings comply with the results of research conducted by Sezgin and Demirer (2016), Çanak and Avcı (2016) and Işık (2016).

Looking at Table 3, it has been determined that the difference between the mean scores on identification level of fans with their teams by the variable of education is insignificant ( $>>0.05$ ). In the research of Okur (2014) on football fans and the study of Tüzün (2006) and Özdemir (2007), no significant difference could be found between education levels and identification level. These results comply with the findings of our research.

Looking at Table 4, it has been determined that the difference between the mean scores on identification level of fans with their teams by the variable of job is insignificant ( $p>0.05)$. The result of the study conducted by Okur (2014) on football fans are similar to our findings. We can say that the variable of job isn't effective on identification of fans with their teams.

Looking at Table 5, it has been determined that the difference between the mean scores on identification level of fans with their teams by the variable of income is insignificant ( $>0.05$ ). The research results of Dilbaz and Kargün (2014), Okur (2014), Baran (2015), Salam (2015) are in parallel to our findings. According to the results of our research, we can say that the variable of income is not effective on identification of the fans with their teams.

Looking at Table 6, it has been determined that the difference between the mean scores on identification level of fans with their teams by the variable of team supported is significant $(\mathrm{p}<0.05)$. It has been determined that this difference emerges between the fans of Elazığspor and Şanlıurfaspor, Yeni Malatyaspor and Amed sportif faaliyetler, Elazığspor and Amed sportif faaliyetler, Büyükşehir Belediye Erzurumspor and Amed sportif faaliyetler, Gazişehir Gaziantep football club and Amed sportif faaliyetler, Gaziantepspor and Yeni Malatyaspor, Şanlıurfaspor and Yeni Malatyaspor teams. Taşğın and Tekin (2007) have determined that fans of Beşiktaş football club are more identified with their teams compared to the fans of Fenerbahçe, Galatasaray and Trabzonspor, Baran (2015) has found a significant difference between the identification levels of fans with their teams by the team they support. According to Wann and Schrader (2000), a fan who sees her/his connection to her/his team as a more important part of her/his identity will have a greater enjoyment when her/his team achieves successful results and will create a greater bond individually. The fact that Yeni Malatyaspor club has obtained successful results and competes in the Super League and other teams play in lower leagues is thought to be effective on the conclusion that the fans of Yeni Malatyaspor are identified with their teams more than the fans of other teams.

In conclusion, it has been established that the variables of age, marital status and the team supported are effective on identification level of fans with their teams while the variables of education, job and income level aren't effective on identification level of fans with their teams, the identification scores of fans with their teams playing in high leagues are high and identification level of fans with their teams reduces as the lower leagues are considered. 


\section{References}

Açak, M., Düz, S., \& Karataş, Ö. Analysis on Fanaticism Situation of Fans in the $1^{\text {st }}$ League of Turkish Football Federation. Atatürk University Beden Ĕ̈itimi ve Spor Bilimleri Dergisi, 20(3), 7-22.

Açak, M., Karabulut, R. (2016). Being Football Club Fan: Evaluation of the Opinions of University Students on Sports Sponsorship. Süleyman Demirel University Sosyal Bilimler Enstitüsü Dergisi Issue: Ciep Special Issue. P.214231.

Aycan, A., Polat, E., \& Uçan, Y. (2009). Analysis on the Relation between the Variables Affecting Team Identification Level and the Decision to Participate in Football Matches as Audience. Spormetre Beden Eğitimi Ve Spor Bilimleri Dergisi, VII(4), 169-174.

Baran, A. (2015). A Study on Determining the Effect of Trademark Identity of Sports Clubs on Team Identification. Dumlupınar University Institute of Social Sciences Department of Business Administration Master's Thesis. Kütahya, 113.

Baş, M. (2008). Fan and Team Identification in Football, Trabzonspor Example. Gazi University Institute of Health Sciences Department of Physical Education and Sports. PhD Thesis. Ankara, 75.

Belk, R., (1988). Possessions and the Extended Self, Journal of Consumer Research, 15(2), 139-168. https://doi.org/10.1086/209154

Çanak, M., \& Avcı, Ö. Y. (2016). Analysis on Organizational Identification and Organizational Communication Levels of Teachers. Uluslararası Eğitim Bilimleri Dergisi, 3, 91-110.

Dilbaz, E., \& Karagün, E. (2014). Factors Affecting Being Audience in Matches and Team Identification Level. Nwsa-Sports Sciences, 9(2), 22-31.

Enginkaya, E. (2014). The Relation between the Attitudes of Football Fans towards Sponsored Brands, Buying Intention and Team Identification. Marmara University İ.İ.B. Journal, XXXVI(II), 145-158.

Gencay, S., \& Karaküçük, S. (2006). A Research on the Behaviors of University Students about Being Sports Fans. Gazi Beden Eğitimi ve Spor Bilimleri Dergisi, 4, 11-22.

Güllü, M., \& Güçlü, M. (2006). Analysis on Team Identification of Secondary School Students with the Teams They Support. $9^{\text {th }}$ International Congress of Sports Sciences Abstract Book. 3- 5 November, Muğla, p.686 - 689.

Günay, T., \& Tiryaki, Ş. (2003). Reliability and Validity Study of Sports Fans Identification Scale (SFIS), Spor Bilimleri Dergisi, Hacettepe Journal of Science, 14(1), 14-26.

Gündüz, M., \& Bayansalduz, M. (2017). Evaluation of Value Judgements Attributed to Football by Turkish Society in terms of the Opinions of Prospective Teachers. Süleyman Demirel University Sosyal Bilimler Enstitüsü Dergisi. 2(27), 81-95

İmamoğlu, A. F., Karaoğlu, E., \& Erturan, E. E. (2007). Structural Qualities and Basic Problems of Sports Clubs in Turkey. Gazi Beden Eğitimi ve Spor Bilimleri Dergisi. X11(3), 35-61.

İmamoğlu, O., Polat, Y., Soygüden, E., \& Barut, Y., (2016). Professional Football Fans and Stadium. Pegem Akademi. 1st Edition. Ankara. P.1

Işık, M. (2016). A Research on the Mediator Role of the Organizational Identification in the Effect of Corporate Reputation Perception on the Job Satisfaction. Dicle University Institute of Social Sciences Department of Business Administration. PhD Thesis. Diyarbakır.p.150

Karaküçük, S. (2005). Recreation: Making Use of Spare Times. Gazi Kitabevi. Ankara. p. 239.

Madrigal, R. (2000). The Influence of Social Alliances with Sport Teams on Intentions to Purchase Corporate Sponsors' Products, Journal of Advertising, 29(4), 13-24. https://doi.org/10.1080/00913367.2000.10673621

Okur, M. (2014). Being Football Fans within the Framework of Identification and Commitment: Bozbaykuşlar. Bahçeşehir University Institute of Social Sciences Department of Sports Management. Master's Thesis. İstanbul. p.48

Özdemir, H. Ö. (2007). The Effect of Corporate Social Responsibility Perceptions of Employees on Organizational Identification, Organizational Commitment and Job Satisfaction: An Application for the Employees of OPET. Marmara University, Institute of Social Sciences, Department of Communication Sciences, Public Relations Department, PhD Thesis, İstanbul. p.148. 
Polat, M. (2009). A Field Study on Premises and Consecutives of Organizational Identification. Uludağ University Institute of Social Sciences Department of Business Administration, Management and Organization. PhD Thesis. Bursa. P.221.

Salam, M. S. (2015). Evaluation of Fan Identification Level and Sponsorship in Football Audiences. Akdeniz University Institute of Social Sciences. Department of Sports Management. Master's Thesis. Antalya. p.68.

Sezgin, N. Ş., \& Demirer, S. (2016). The Relation between the Organizational Socialization of Teachers, Their Identification Levels and Working Competences. Abant İzzet Baysal University Eğitim Fakültesi Dergisi, 16(1), 237-269.

Taşğın, Ö., \& Tekin, M. (2007). A Research on Football Fans' Creation of Brand Value. Selçuk University Sosyal Bilimler Dergisi, 18, 447-454.

Taşmektepligil, Y., Yılmaz, Ç., İmamoğlu, O., \& Ağaoğlu, Y. S. (2006). Realization Level of Physical Education Extracurricular Targets in Primary Schools and Evaluation of New Approaches in This Matter. 9th International Congress of Sports Sciences. 3 - 5 November, Muğla.

Tüzün, K. İ. (2006). The Relation between Organizational Confidence, Organizational Identity and Organizational Identification, An Applied Study. PhD Thesis, Gazi University, Institute of Social Sciences, Department of Business Administration, PhD Thesis. Ankara. P.141.

Underwood, R., Bond, E., \& Baer, R. (2001). Building Service Brands via Social Identity: Lessons from the Sports Marketplace. Journal of Marketing Theory and Practice, 9(1), 1-13

Wann, D. L., \& Branscombe, N. R. (1993). Sports Fans: Measuring Degree of Identification with Their Team, International Journal of Sports Psychology, 24 (1), 1-17.

Wann, D. L., \& Schrader, M. P. (2000). Controllability and Stability in the Self-Serving Attributions of Sport Spectators. The Journal of Social Psychology, 140, 160-168. https://doi.org/10.1080/00224540009600455

\section{Copyrights}

Copyright for this article is retained by the author(s), with first publication rights granted to the journal.

This is an open-access article distributed under the terms and conditions of the Creative Commons Attribution license which permits unrestricted use, distribution, and reproduction in any medium, provided the original work is properly cited. 